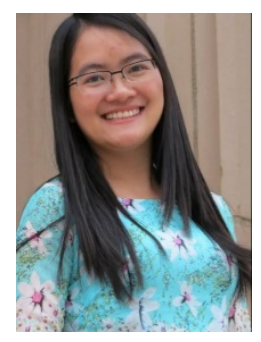

\title{
Integrating VoiceThread into EFL Speaking Class
}

\author{
Trang Ho
}

Ha Long High School for Gifted Students, Quang Ninh Province

\begin{abstract}
In EFL classrooms, teaching speaking is difficult because of limited time, students' inhibitions, and low participation. Incorporating VoiceThread into EFL speaking classes can help with students’ anxiety and encourage shy students to participate in multiple conversations. It also motivates students as they can add images and videos to create presentations.
\end{abstract}

\section{Session Description}

One of the ultimate goals of Vietnam’s Teaching and Learning Foreign Languages in The National Education System, Period 2008 - 2020 Project (2008) states “by the year 2020 most Vietnamese youth whoever graduate from vocational schools, colleges and universities gain the capacity to use a foreign language independently” (p. 1). The project also indicates that in order to fulfill this goal, the integration of information technology in the classroom is a must. VoiceThread, a computer tool which is easily accessible, cost effective, and adaptable to many learning settings (Brunvand \& Byrd, 2011) is extremely helpful in developing students’ oral competency and encouraging students to speak. This presentation shows how it is possible to integrate VoiceThread into EFL speaking class by (a) guiding the participants through the process of setting up VoiceThread accounts, (b) familiarizing them with VoiceThread’s basic functions, (c) demonstrating step-bystep a lesson plan which utilizes VoiceThread, and (d) suggesting inside and outside classroom speaking ideas using VoiceThread. The presenter will also allow time for a discussion on some pitfalls in integrating VoiceThread into EFL speaking class and encourage participants to share their own ideas of using VoiceThread. This presentation is intended for EFL high school teachers interested in incorporating pedagogical knowledge and skills with technology to enhance their ability to teach speaking. 


\section{References}

Brunvand, S., \& Byrd, S. (2011). Using VoiceThread to promote learning engagement and success for all students. Teaching Exceptional Children, 43(4), 28-37.

Vietnam Ministry of Education and Training. (2008). Teaching and learning foreign languages in the national education system, period 2008-2020, 1-11. Retrieved April 26, 2016, from http://jpf.org.vn/iwtcore/uploads/2012/08/1-3Decision_1400_QD-TTg-Eng.pdf 